\title{
English Instructional Video Design for Islamic Junior High School
}

\author{
Rifqi Aulia Erlangga, Izzati Shaima Shamsudin \\ IAIN Salatiga, Indonesia \\ Universiti Kebangsaan Malaysia, Malaysia \\ 07rifqi@gmail.com; izzatishaima@gmail.com
}

\begin{abstract}
The purpose of this study is to investigate the perceptions of teachers and students in Islamic Junior High School about duration, their involvement in the video (cast), format and post-video watch activities of English supplementary videos to ensure the videos that will be made are effective. Using a descriptive quantitative method, this study reveals that video is a fun learning tool to study English, so that the students don't mind if the video duration is more than 15 minutes. About the cast, the students inclined to be involved in producing the video. About the format, the majority chooses the drama method with Bahasa subtitled. About the post-video watch activities, they prefer to do a writing rather than a speaking activity. During the video playing, they didn't taking a note or observing the whole plot yet, so that they wish the video can be replayed outside the class, just like on television or youtube.
\end{abstract}

Keywords: . English, learning media, video, Islamic Junior High School Permalink/DOI: https://doi.org/10.18326/infsl3.v15i1.141-162 


\section{Introduction}

Traditional teaching process can no longer serve the primary function of disseminating content, which can be found at any time in a variety of online video teaching repositories (Giannakos et al., 2016). Erlangga (2016) and Moerdiyanto (1989) revealed that students need supplementary instructional platforms to make English learning process more enjoyable and effective. Video-based learning (VBL), which is characterized as the systematic use of video tools to acquire defined information, competence, and skills, have become increasingly popular as in recent years (Pappas et al., 2016).

The Indonesian government realizes the importance of VBL, and has made efforts to make the instructional videos, particularly English learning videos. However, according to Erlangga (2016), official government instructional videos have no major effect on students' English performance since they only show a teacher teaching in a manner close to ordinary classroom learning. In the presence of the fact that children in general feel very comfortable in front of the television, following television principles can be used to create videos that will improve students' performance while still being entertaining (Anderson \& Pempek, 2005). After repeated, TV shows that they have watched are still gluing in their memory, unlike when they study formally. Therefore, a learning medium that can produce the same impact on students, voluntarily following and repeating it, needs to be made. Students are expected to enjoy English learning video like television broadcast products, which they repeatedly watch but never get tired of it (Le Fevre, 2003).

The video that will be produced following the television standards must be designed by considering the duration, format, watching period and student experiment (Giannakos et al., 2016). Students' experiences can be obtained when they are involved in the video making process. Students perform better while they are personally involved in the learning activity (physically and/ or intellectually) (Bott, 2014)toxic chemical products formed as secondary metabolites by a few fungal species that readily colonise crops and contaminate them with toxins in the field or after harvest. Ochratoxins and Aflatoxins are mycotoxins of major significance and hence there has been significant research on broad 
range of analytical and detection techniques that could be useful and practical. Due to the variety of structures of these toxins, it is impossible to use one standard technique for analysis and/or detection. Practical requirements for high-sensitivity analysis and the need for a specialist laboratory setting create challenges for routine analysis. Several existing analytical techniques, which offer flexible and broad-based methods of analysis and in some cases detection, have been discussed in this manuscript. There are a number of methods used, of which many are lab-based, but to our knowledge there seems to be no single technique that stands out above the rest, although analytical liquid chromatography, commonly linked with mass spectroscopy is likely to be popular. This review manuscript discusses (a. Involving students in the production of learning videos is one way to make it more successful (Tegeh et al., 2019). It is hoped that by having students playing role in the instructional video, the video would pique their attention. Furthermore, students can gain more experience through the practice of creating videos on their own.

According to Lackmann et al. (2021), video's format with lecture capture causes greater emotional involvement for a shorter period of time, while the higher the student participation, the better the student results, though the relationship is quadratic in the case of cognitive engagement (inverted $U$ shaped). Instructional video formats can be made in the form of tutorials, interactive or drama (Erlangga et al., 2016). Each video format has its own supportive previous studies. Interactive multimedia learning has a positive influence on the learning process and outcomes (Hung et al., 2018; Riana \& Gafur, 2015; Seckman, 2018)interactive video lectures are increasingly being adopted in digital learning contexts for increasing interactivity. However, conventional video lecture lacks interactive learning activities (ILAs. The use of video tutorials aided in the learning process, and students obtained excellent results (Preradovic et al., 2020). However, drama is more successful at attracting a wider audience, igniting initial curiosity, and educating students, but interactive video is best at demonstrating finer details of the material (George et al., 2018).

Previous research that reviewed the instructional videos 
presented the duration of the video with an average viewing time of 3.9 minutes (Chung, 1999; Huang \& Eskey, 1999; Markham \& Peter, 2003; Montero Perez et al., 2014). Rodgers \& Webb (2017) find that the student's post-activity scores were only substantially different for three of the ten episodes of 42-minute American television program. Since this is correlated with human memory capacity and the ability to focus is very restricted between 15-20 minutes, learning media using video must have a length of between 20-40 minutes (Syaparuddin \& Elihami, 2020).

The use of English learning videos has its own purpose. It could be to improve children's speaking skills (Chien et al., 2020), or it could be to improve children's writing skills (Wahyuni, 2015), but it is, of course, to improve children's English skills in general. In order to achieve the goal (whether it is speaking or writing skill), giving activities after watching videos is the important key. Some of the activities that can be done after watching the video are discussion, written-test and redemonstration the role on the video (Nurhidayat \& Syarifah, 2019).

Based on the explanation above, this research aims to investigate the student's and teachers' perceptions regarding the ideal design of English learning videos. The participation of students in the video, video's format, video's duration, and postactivities that are deemed the most comfortable for both students and teachers are some of the items that will be discussed in this research. Since students and teachers are the main consumers of the learning media, a more entertaining video that is built from their perspective is unquestionably needed. Students require supplements that will make the learning experience more fun and successful in enhancing their motivation and passion for learning English. The videos targeted to students' and teachers' needs are intended to be able to meet this need as well.

\section{Instructional Video Making}

Jack Koumi is a figure found in literature observation. He is an education media trainer who gave tens of training in 20 more countries around the world. Previously, he worked at BBC Open 
University Production Center, producing audio and video programs in Science and Mathematics. In his book "Designing Video and Multimedia for Open and Flexible Learning" (Koumi, 2006), he stated that at least there are four categories (from education value) that can be inserted in a video so that it can be used for teaching and learning process for students. The strengths of video use focus on:

In the video-making process, the first thing to consider is what to teach on video and how to teach it. In this part, it needs teachers' role to be involved in video making. The teachers know what students need and understand how to deliver it in the form of video. By understanding the condition and other things related to students, teachers highly recommend and suggest that later will be combined with TV video making experts' opinions (Koc, 2011).

The second thing is when to choose and how to use other media for teaching. Selecting and using media are necessary. "Selecting" here should be done very carefully and consider many aspects, such as education aspects, possible psychological impact after students using media, and so forth. Using it means to predict and design a good lesson plan on the use of the media in class. The usage should appropriate to students' conditions, schools, and students' competence (Ala-Mutka, 2011).

The third thing is a framework of pedagogic design principles for video and multimedia (Koumi, 2014). In this case, video or multimedia use must meet the requirement of teaching material. Since every teacher has his/ her particular style, so are students, the usage has to focus on English teaching, including moral value. For example, throwing litter in the right place, sharing with others, etc.

The fourth thing is practical development advice for interactive multimedia. It is necessary to work with media experts since it does not only accommodate teachers' opinions. The role of media experts will give quality to this product video that will trigger studentsteachers interaction. Students will not only focus on watching, but there are strategies and outstanding design that will make it more optimal to help teachers teach in a fun way (Ariyani et al., 2018). 


\section{Audio-Visual Media}

According to James in Dash \& M. Dash (2007), audio-visual aids (instructional materials) are devices that can make the learning experiences more concrete, more realistic, and more dynamic. One of the interesting audio-visual media in learning is the television and video. Video is a form of multimedia that conveys information through two simultaneous sensory channels: aural and visual. It often uses multiple presentation modes, such as verbal and pictorial representations, in on-screen print and closed-captioning (Cruse, 2011). According to Badjuri (2010), television is audio-visual media, in which people are not just looking at pictures televised, but at the same hearing online TV or digest narrative of the picture. The television is instrument in influencing the mental and mindset of public. There are many discussions on the impact of these audiovisual media in the teaching learning activities. Some of the previous research I had found and analyzed are described on the following paragraphs.

The first previous research related to the Sesame street program is from Ball \& Bogatz (1971). They stated that the application of their two principles in the summative research for Sesame Street caused them us to assess at pretest and posttest times not only progress along some 36 primary goals of the show but also transfer effects, home background variables, parental attitudes, and socioeconomic status factors. Among 3 to 5 years-old children with the number over 1,300. They observed many of them viewing the show, made a content analysis of the show itself, administered a questionnaire to teachers whose classes viewed the show, and assessed the amount of viewing for all the subjects in the study using our different assessment techniques. When evaluating a program in which sideeffects and interactions are considered important, the study has to be wide-ranging, the sampling extensive, and the statistics multivariate. Their result showed that student achieve significant improvement in their academic score.

The first previous research related to the Sesame street program is from Fisch (2014). She claimed that the foreign can be promoted through the use of television in school. Norland (1990) reported that an Israeli study found significant improvement in low-IQ children's 
comprehension of English after viewing a series of English-language programs in school, and that a Swedish study found similar effects from English-language programs that were subtitled in Swedish.

On the other part of the book, Fisch (2014) stated that educational television's motivational impact had significant effects in some areas, and they have varied by age. The result from the children' parents stated that among kindergartners, parents and teachers reported no difference in children's looking at books or magazines alone, talking with others about books, writing during free time in school, or the frequency with which they asked others to read to them. However, parents reported kindergarten viewers' going to libraries or bookstores more and writing significantly more letters, notes, and stories than nonviewers at posttest. The only significant effects for first graders were in parents' ratings of the frequency with which children read books alone and teachers' writing reports during free time (Linebarger, 2001).

The second research review about the impact of Sesame street program is stated by Fisch (2005). He stated on his research resume that children among 3- to 5-year-olds who had view Sesame Street showed significant improvement in their academic skills related to the alphabet, numbers, body parts, shapes, relational terms, and sorting and classification. Fisch (2005) also said that students' school readiness, such as verbal readiness, quantitative readiness, attitude toward school, and relationships with peers are developed well by watching Sesame Street. Results also indicated that children who had been frequent Sesame Street viewers were rated as better prepared for school than their non- or low-viewing classmates.

On the last statement of Fisch (2005), the longest-term impact of Sesame Street was found in a study that examined high school students who had watched more educational television and Sesame Street in particular as preschoolers had significantly higher grades in English, Mathematics, and Science in junior high or high school. They also used books more often, showed higher academic selfesteem, and placed a higher value on academic performance. As the addition, in relation to the academic effects of educational television, Fisch (2005) stated that numerous studies have found that viewing 
prosocial television program produces significant positive changes in children social behavior.

\section{Islamic Content Instructional Video}

Law No.20 of 2003 Article 1 paragraph 2 states that national education is education based on Pancasila and the 1945 Constitution and is rooted in religious values, Indonesian national culture and responsive to the demands of changing times (Undang-Undang Republik Indonesia No. 20 Tahun 2003 Tentang Sistem Pendidikan Nasional, 2003). As a result, religion and cultural identity must be included in the education program (curriculum) (Suradi, 2018; Suyadi, 2019). Islam as the majority religion and eastern culture of Indonesia has a similar character, namely has strong faith in God, noble character, health, erudition, capability, sovereignty, independency, and responsibility (Rahman et al., 2019). Islamic education aims to create human beings that are truthful, reasonable, humane, ethical, compassionate, disciplined, harmonious, and efficient, both personally and socially, by observing the guidelines that religion is taught to humans with the vision of realizing people who fear Allah SWT and have noble values (Winarno, 2012). As a means of analytical adaptation, Indonesian culture has an impact on the formulation of attitudes, values, decency norms, and problemsolving methods (Siswanta, 2017). Therefore, it is permissible if Islamic material is used in subjects other than religious education, such as English, especially in Islamic School.

English lessons at school officially begin when children enter junior high school education (Kemdikbud, 2014). Previously, English was introduced and taught at the elementary school level, but the regulation of the Minister of Education and Culture of the Republic of Indonesia number 81A of 2013 (Kementerian Pendidikan dan Kebudayaan Republik Indonesia, 2013) decided that English for elementary students is nowadays becoming as local content. The explanation above means that elementary schools have the freedom to include English as part of their subjects or not. Based on these facts, it generally assumed that junior high school level is the first level for students to learn English. The video's content produced in the follow-up research will be ideal for middle school-aged children and will include Islamic content. Any of the content intended for 
later is set in a mosque and has a theme of foreigner tolerance. Since this video necessitates student participation, the study will take place in Islamic junior high schools.

\section{Methods}

This research is executed by quantitative approach with two kinds of data used, they are primary and secondary data. Primary data is obtained from questionnaire distribution, either open or closed questionnaire and interview the respondents. The respondents include (1) Students of Islamic junior high school in Semarang, by conducting a random sampling, we got 188 students; (2) English teachers, there are five English teachers who lend their hands to give their input and suggestions for the development of the product.

The secondary data used is data obtained from some literature related to this research, data about the research subject is obtained from journal, books and websites that support this research. Students, teachers are given questionnaire then interviewed to obtain the following data: (1) teaching material used by teachers, (2) students' result in English lesson, (3) what kind of media students and teachers can use to improve to study English in class. According to the procedure, after questionnaire distribution, interview to students and teachers will be followed by video-taping. Questions during the interview focus on the questionnaire to cross-check the result of the questionnaire, the flowing confirmation is also conducted towards the headmaster.

\section{Result \& Discussion}

Student's View on English Lesson

The students are required to state their opinion about English becoming one of the lessons they need to take at school and their motivation to learn this lesson. The point will be presented on three number (table 1) below.

Table 1. Student's Perceptions on English Lesson

\begin{tabular}{lll}
\hline No. & Statement & Elaboration \\
\hline 1 & $\begin{array}{l}\text { I think English is a fun } \\
\text { subject. }\end{array}$ & $\begin{array}{l}\text { I think learning English is a fun } \\
\text { thing to do. }\end{array}$ \\
\hline
\end{tabular}




\begin{tabular}{|c|c|c|}
\hline No. & Statement & Elaboration \\
\hline 2 & $\begin{array}{l}\text { I think it is easy speaking in } \\
\text { English. }\end{array}$ & $\begin{array}{l}\text { The students think that English } \\
\text { is an easy lesson. }\end{array}$ \\
\hline 3 & $\begin{array}{l}\text { I'd love to speak English } \\
\text { fluently. }\end{array}$ & $\begin{array}{l}\text { The students is motivated to } \\
\text { learn English. }\end{array}$ \\
\hline
\end{tabular}

Source: Authors documentation

The respondent's answer will provide mean score. Mean score is the one that will be compared above in Likert scale. On the descriptive statistic result, the mean for question no. 1 is 4,19 . If we were to compare to the Likert Scale, the result shows that English is a fun subject. The mean results for question no. 2 is 3,38 . It shows that the respondent is uncertain that English is an easy subject. The question no. 3 is expected to give suficcient answer whether the students possess the motivation to learn English. The mean score for question no. 3 is 4,25. It indicates that the students are agree that they want to learn English better and they are highly motivated to learn English. The result from the three questions above shows that eventhough the students hesitate to answer whether English is an easy subject, the students agree that English is a fun and interesting subject to learn and they are motivated to learn more. In order to make the students willing to learn English in fun and leisure manner, video learning is implemented.

\section{Student's Perception on Instructional Video}

Based on the result on student's view on English learning above, it shows that the students agree that English is a fun subject to learn. But they think it is not easy to learn English. Therefore, they will be assisted to learn by watching video. Before the product is developed, it will need further review on whether the students need video as learning aids. The review will be conducted by figuring on student's view on video learning. The question will be divided on 6 questions as written on the following table 2.

Table 2. Student's Perception on Instructional Video

\begin{tabular}{lll}
\hline No. & Question & Elaboration \\
\hline 4 & $\begin{array}{l}\text { I think that video is a fun thing } \\
\text { to do. }\end{array}$ & $\begin{array}{l}\text { The students think that video } \\
\text { is a fun thing to do. }\end{array}$ \\
\hline
\end{tabular}




\begin{tabular}{lll}
\hline No. & Question & Elaboration \\
\hline 5 & $\begin{array}{l}\text { I think English will be fun to } \\
\text { learn if the teacher play the } \\
\text { video. }\end{array}$ & $\begin{array}{l}\text { The students think learning by } \\
\text { watching video is fun. }\end{array}$ \\
23 & $\begin{array}{l}\text { I think English video learning } \\
\text { can help me speaking in }\end{array}$ & $\begin{array}{l}\text { The students think it will help } \\
\text { to learn speaking in English by } \\
\text { watching video. }\end{array}$ \\
& $\begin{array}{l}\text { After the video is played and } \\
\text { English lesson is over, I want } \\
\text { to be able to speak English and } \\
\text { do English homework. }\end{array}$ & $\begin{array}{l}\text { The students will be motivated } \\
\text { to learn English more after } \\
\text { watching video. }\end{array}$ \\
25 & $\begin{array}{l}\text { I think the English video } \\
\text { learning helps me to speak } \\
\text { English correctly based on the } \\
\text { original pronounciation. }\end{array}$ & $\begin{array}{l}\text { The students think that } \\
\text { watching video will improve } \\
\text { their speaking ability. }\end{array}$ \\
26 & $\begin{array}{l}\text { I think English learning video } \\
\text { enable me to converse better in }\end{array}$ & $\begin{array}{l}\text { The students think that } \\
\text { watching video will improve } \\
\text { English. }\end{array}$
\end{tabular}

Source: Authors documentation

Dicussing the questions of no. 4 and no. 5 , the mean points at 4,56 and 4,50. It shows that the respondents are agree that learning by watching video is a fun thing to do. Question no. 23, 25, and 26 indicates that the respondents in general shares similar thought that learning by watching video can help their speaking ability. Whereas no. 24 shows that the students in general agree that learning via video will improve their motivation to learn English.

\section{Video Duration}

The questionnaire will include how long the video duration so that the students will effectively absorb the lesson. The question about video duration will be presented on no. 6 ("Watching English learning video more than 15 minutes makes me bored."). Based on the result, it is concluded that the respondent agree that the learning based on watching video is fun, so that they do not mind video duration is more than 15 minutes-long. The supplement is a subject matter that does not replace the primary material such as official 
books from schools but only as a companion or supplement. For example, an English class run for 2 hours, so the video is enough to use for 10-30 minutes from a total of 120 minutes of learning time.

The Video Cast and the Involvement of Students in Producing Video The following step in analyzing student's need is to cast people based on respondent's preferance and also whether the students are willing to take part in producing the video. There will be 8 questions as stated on the following table 3 .

Table 3. The Video Cast and The Involvement of Students in Producing Video

\begin{tabular}{|c|c|c|}
\hline No. & Question & Elaboration \\
\hline 7 & $\begin{array}{l}\text { The English video learning will } \\
\text { be more interesting the foreigner } \\
\text { take part as casts in the video. }\end{array}$ & The cast is a native speaker. \\
\hline 8 & $\begin{array}{l}\text { The English video learning will } \\
\text { be more interesting if the cast is } \\
\text { Indonesian. }\end{array}$ & The cast is Indonesian. \\
\hline 9 & $\begin{array}{l}\text { The English video learning will } \\
\text { be more interesting if the cast is } \\
\text { Indonesian and foreigner. }\end{array}$ & $\begin{array}{l}\text { The cast is both Indonesian } \\
\text { and foreigner. }\end{array}$ \\
\hline 10 & $\begin{array}{l}\text { If the teacher asked me to make } \\
\text { English video learning, I am glad } \\
\text { to do it. }\end{array}$ & $\begin{array}{l}\text { The students have the will } \\
\text { to be involved in producing } \\
\text { video. }\end{array}$ \\
\hline 11 & $\begin{array}{l}\text { I am glad that I make a video with } \\
\text { foreigner cast. }\end{array}$ & $\begin{array}{l}\text { The students have the will } \\
\text { to be involved in producing } \\
\text { video. }\end{array}$ \\
\hline 12 & $\begin{array}{l}\text { I am glad that the people outside } \\
\text { school involved in the English } \\
\text { video learning that I produce. }\end{array}$ & $\begin{array}{l}\text { The students have the will } \\
\text { to be involved in producing } \\
\text { video. }\end{array}$ \\
\hline 13 & $\begin{array}{l}\text { I think that it will be fun if } 2-3 \\
\text { cast included in the English video } \\
\text { learning. }\end{array}$ & $\begin{array}{l}\text { The cast is small group of } \\
\text { people. }\end{array}$ \\
\hline
\end{tabular}




\begin{tabular}{lll}
\hline No. & Question & Elaboration \\
\hline 15 & $\begin{array}{l}\text { I think practicing English video is } \\
\text { more interesting than producing } \\
\text { the video. }\end{array}$ & $\begin{array}{l}\text { The students do not have } \\
\text { the will to be involved in } \\
\text { producing video. }\end{array}$ \\
\hline
\end{tabular}

Source: Authors documentation

The answers to questions 7,8 , and 9 in the table above pertain to the cast of the video. The graph depicts the high average point on query number nine. It demonstrates that the respondent is prefer Indonesian than the native speaker to play the role. The respondent's response to question 13 indicates that he or she is willing to cast people in small groups. In response to questions 10, 11, and 12 about students' interest in making video, the outcome indicates that the student is hesitant to participate in video production. Issue 15 is the polar opposite of questions 10,11 , and 12 . It supports the claim that the respondent prefers to only watch videos rather than participate in their development.

\section{Video Format}

There will be 5 questions as stated on the following table 4. The students are required to provide answer about video format, whether it is conducted in interactive method, dialogue method, or drama method. The majority preference chooses drama method; in which this method attains highest mean and modus. On the question whether there will be provided explanation in Indonesian, the majority solidly answer that the students agree. The last question is to recognize the need of instruction in the beginning of the video. The result shows that the students are uncertain if they need the instruction.

Table 4. Video Format

\begin{tabular}{lll}
\hline No. & Question & Elaboration \\
\hline 14 & I think that English video & The video must include \\
learning will not include & explanation in Indonesian. \\
& $\begin{array}{l}\text { Indonesian, it will be hard for } \\
\text { me to understand. }\end{array}$ &
\end{tabular}




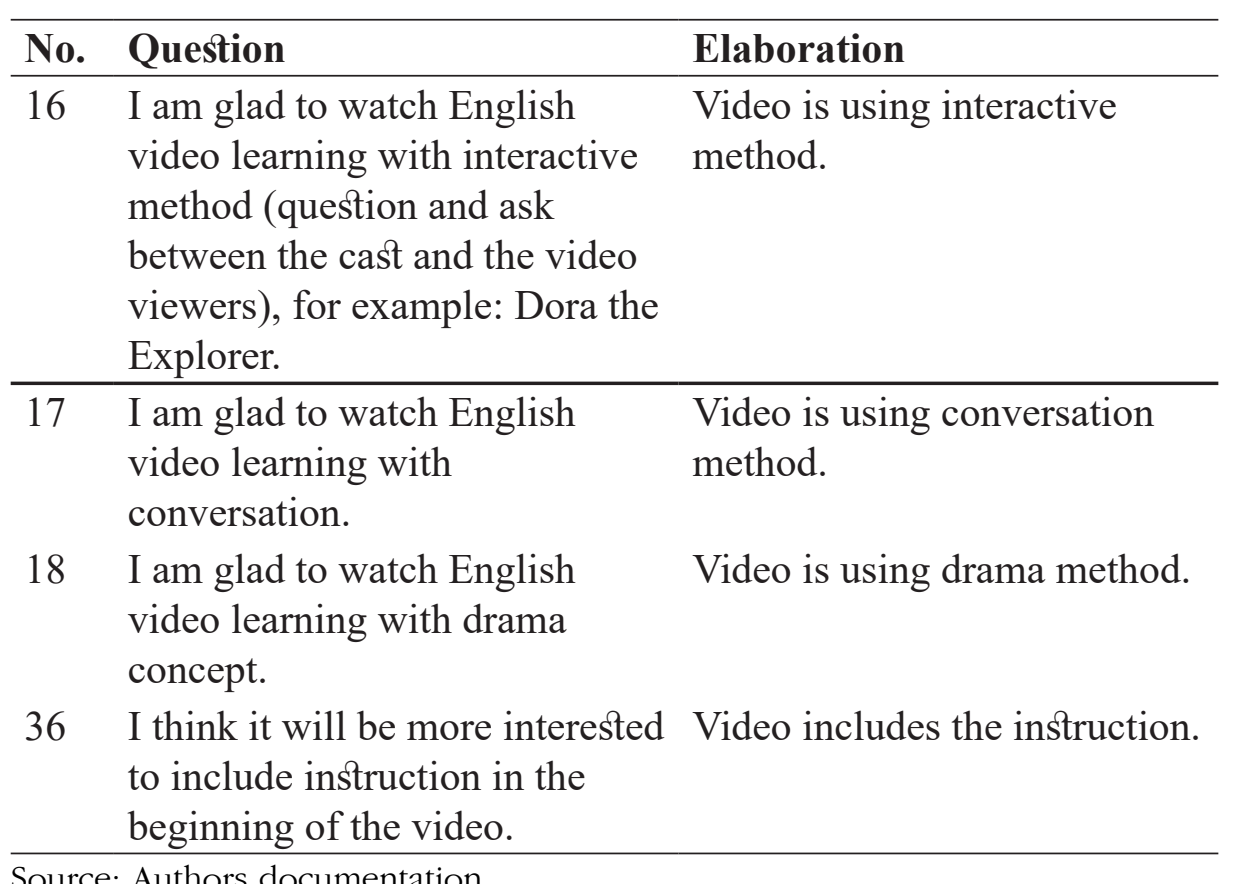

Post-video learning activity

After watching English video learning, there will be one activiy to ensure that the learning is effectively done. There are many kinds of activity, including re-watching the video, doing task regarding the video lesson, etc. The students are required to provide answer on what activity they want to do as stated on the table 5 below.

Table 5. Post-Video Watching Activity

\begin{tabular}{lll}
\hline No. & Question & Elaboration \\
\hline 19 & $\begin{array}{l}\text { I am glad to do practice after } \\
\text { watching the video. }\end{array}$ & Speaking practice activity. \\
20 & $\begin{array}{l}\text { I am glad to do question and } \\
\text { answer with the teacher after }\end{array}$ & Speaking practice activity. \\
& $\begin{array}{l}\text { watching the video. } \\
\text { I am glad to do assignment after } \\
\text { watching the video. }\end{array}$ & Writing practice activity.
\end{tabular}




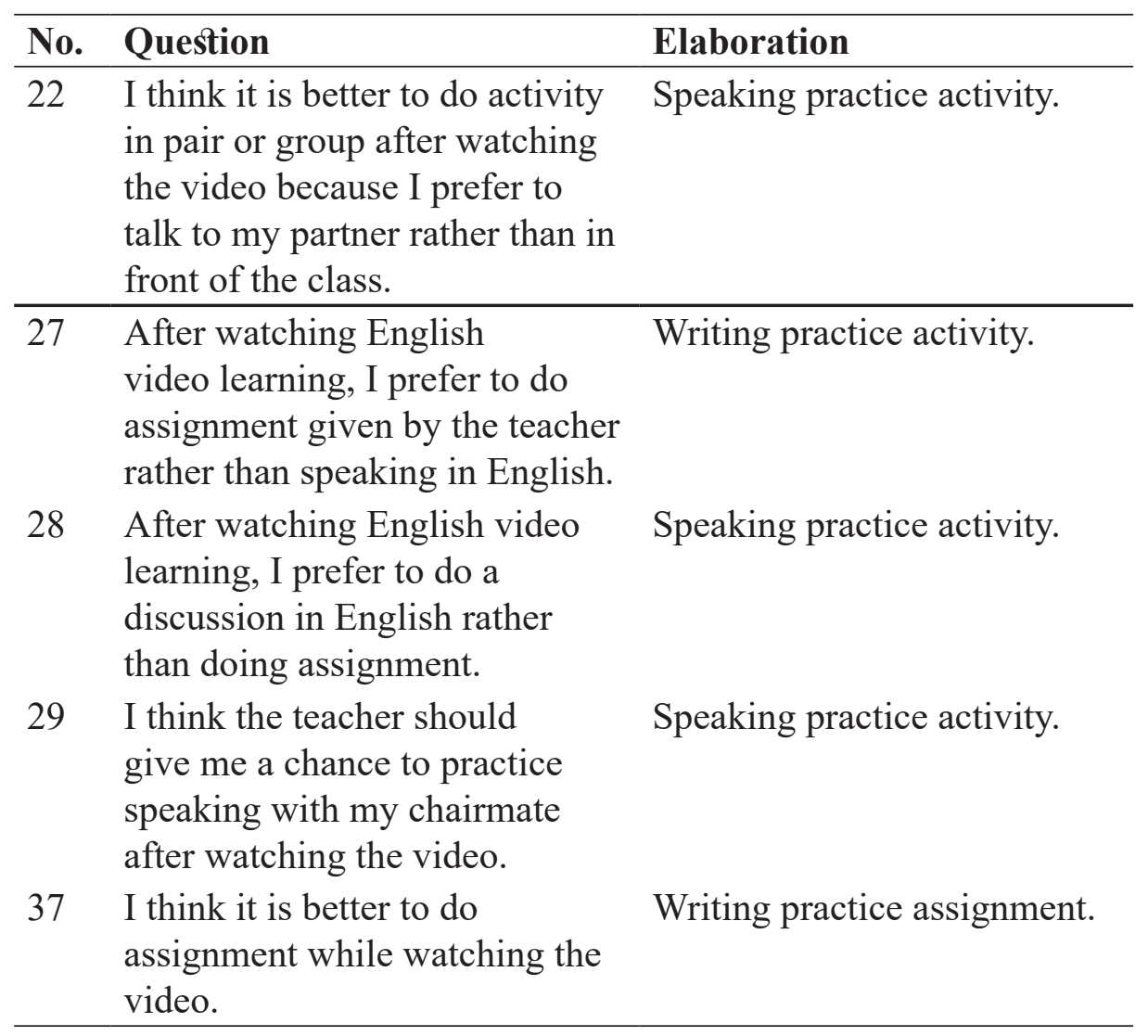

Source: Authors documentation

The descriptive statistic result of the post-video learning activity on choosing speaking or writing; the students in general prefers writing activity.

\section{Teacher's Perception}

Beside the students, we also asked for English teachers perception about their ideal design of instructional video. They are: (1) It is not easy to teach speaking English for students, plus some facts that majority of students were not certain that English is an easy lesson. To answer about learning English easily, the teacher said that although students were not fluent to speak English yet, positive responses can be seen when the teacher insert the video in her class. At the end, it can be concluded that from teachers' point 
of view, learning English, especially speaking, the use of video is highly needed.; (2) In contrast to students who had no issues with video length, the instructor claimed that as long as the video was no longer than 15 minutes, it was effective to incorporate; (3) It suggests that the teachers agreed with the students that making a video with Indonesians would be beneficial (4) The total number of actors was supposed to be 1-3 people, to make effective video; (5) Teachers could participate in video making. The teacher said that if teachers participated in the video, it would eliminate students' doubts to get involved in the video. The students and teachers' figures could be an option to be present in the video; (6) The teacher recommended making a video of interactive models and dialog; (7) It is quite certain that without using Bahasa, students would understand the video, but it still be better to give the subtitle to make the video more understandable; (8) Both teachers and students hoped that video access could be reached by TV and YouTube channel.

\section{Conclusion}

Based on the finding of this research, the research has concluded that the use of this English learning video can help teachers in improving their class more interesting for students. As a supporting material, this video product gives some implications. From video, students don't only study from text but also from actors' glance, gestures, facial expressions to deliver a message. Since the video touches many aspects, like background, costume, situation, intonation and facial expression which is familiar to students, the video has some opportunities for students to guess and understand the content of the video even when student cannot understand the dialog.

There are some recommendations from the teachers and students due to the ideal design of instructional video. First, the duration is no more than 15 minutes. Second, the cast is better the Indonesian rather than the native speakers (foreigners). The students refuse to get a role in the video, but the teacher can be involved as an actor in the video. Third, the drama format was preferred by students to the tutorial or interactive format, but for teachers the interactive format was much more interesting. Fourth, students were more likely to be given a written exam as a post-activity than to be asked to re-enact the video's conversations, but re-enacting 
the video's conversations was the most beneficial method for the teacher to practice the students' speaking skills. And the last but not least, both students and teachers agreed that video access could be reached by TV and YouTube channel that it would be great.

This study has some limitations, including the fact that it only discusses four aspects of video design: duration, cast and student participation in video production, video's format, and post video watching activity. Matters relating to the content of video have not been discussed in this study and are expected to be investigated in further research. This research was made in order to prepare English instructional videos for Islamic Junior High students. Videos will be made in accordance with the input of students and teachers that have been obtained from this research.

\section{References}

Ala-Mutka, K. (2011). Mapping Digital Competence: Towards a Conceptual Understanding. Institute for Prospective Technological Studies, 60. http://ftp.jrc.es/EURdoc/JRC67075_ TN.pdf\%5Cnftp://ftp.jrc.es/pub/EURdoc/EURdoc/JRC67075_ TN.pdf

Anderson, D. R., \& Pempek, T. A. (2005). Television and Very Young Children. American Behavioral Scientist, 48(5), 505522. https://doi.org/10.1177/0002764204271506

Ariyani, F., Nayana, T., Saregar, A., Yuberti, Y., \& Pricilia, A. (2018). Development of Photonovela with Character Education: As an Alternative of Physics Learning Media. Jurnal Ilmiah Pendidikan Fisika Al-Biruni, 7(2), 227. https://doi. org/10.24042/jipfalbiruni.v7i2.3072

Badjuri, A. (2010). Jurnalistik Televisi. In Perpustakaan Nasional RI. Graha Ilmu.

Ball, S., \& Bogatz, G. A. (1971). Summative Research of Sesame Street: Implications for the Study of Preschool-Aged Children. In Sesame Street. 
Bott, R. (2014). Video in Theory and Practice: Issues for Classroom Use and Teacher Video Evaluation. Igarss, 1, 1-5. https:// www.ebiomedia.com/downloads/VidPM.pdf

Chien, S. Y., Hwang, G. J., \& Jong, M. S. Y. (2020). Effects of Peer Assessment within the Context of Spherical Video-based Virtual Reality on EFL Students' English-Speaking Performance and Learning Perceptions. Computers and Education, 146, 103751. https://doi.org/10.1016/j.compedu.2019.103751

Chung, J. M. (1999). The Effects of Using Video Texts Supported with Advance Organizers and Captions on Chinese College Students' Listening Comprehension: An Empirical Study. Foreign Language Annals, 32(3), 295-308. https://doi. org/10.1111/j.1944-9720.1999.tb01342.x

Cruse, E. (2011). Using Educational Videos in Classrooms.

Dash, N., \& M.Dash. (2007). Teaching English as an Additional Language. Atlantic Publishers.

Erlangga, R. A. (2016). Enhancing Students' Speaking Skills through "Kunci Inggris" Videos in Islamic Junior High School. Journal of Education and Practice, 7(36), 170-180.

Erlangga, R. A., Saleh, M., Rukmini, D., \& Sofwan, A. (2016). Empowering Students of International Class Programiain Salatiga in the Production of Praying Tutorial Video. Inferensi, 10(2), 427. https://doi.org/10.18326/infsl3.v10i2.427-450

Fisch, S. M. (2005). Children's Learning from Television It's not just "violence." Televizion, 10-14.

Fisch, S. M. (2014). Children's Learning from Educational Television: Sesame Street and beyond. In Children's Learning from Educational Television: Sesame Street and Beyond. Lawrence Erlbaum Associates. https://doi.org/10.4324/9781410610553

George, W., Jimmy, P., Charles, M., \& Zeyaur, K. (2018). An Assessment of Effectiveness of Parcipatory Video and Drama in Enhancing Learning of Climate Smart Push-Pull Technology. International Journal of Agricultural Extension, 06(02), 109116. 
Giannakos, M. N., Jaccheri, L., \& Krogstie, J. (2016). Exploring the Relationship between Video Lecture Usage Patterns and Students' Attitudes. British Journal of Educational Technology, 47(6), 1259-1275. https://doi.org/10.1111/bjet.12313

Huang, H.-C., \& Eskey, D. E. (1999). The Effects of Closed-Captioned Television on the Listening Comprehension of Intermediate English as a Second Language (ESL) Students. Journal of Educational Technology Systems, 28(1), 75-96. https://doi. org/10.2190/rg06-lywb-216y-r27g

Hung, I. C., Kinshuk, \& Chen, N. S. (2018). Embodied interactive video lectures for improving learning comprehension and retention. Computers and Education, 117, 116-131. https:// doi.org/10.1016/j.compedu.2017.10.005

Kemdikbud. (2014). Peraturan Menteri Pendidikan dan Kebudayaan Republik Indonesia No.58 Tahun 2014 tentang Kurikulum 2013 Sekolah Menengah Pertama/Madrasah Tsanawiyah. In Menteri Pendidikan Nasional. https://doi.org/10.1093/eurheartj/ eht160

Kementerian Pendidikan dan Kebudayaan Republik Indonesia. (2013). Peraturan Menteri Pendidikan dan Kebudayaan Republik Indonesia No. 81 A tentang Implementasi Kurikulum (Salinan). https://doi.org/10.4324/9781315853178

Koc, M. (2011). Let's Make a Movie: Investigating Pre-service teachers' Reflections on Using Video-recorded Role Playing Cases in Turkey. Teaching and Teacher Education, 27(1), 95106. https://doi.org/10.1016/j.tate.2010.07.006

Koumi, J. (2006). Designing video and multimedia for open and flexible learning. Designing Video and Multimedia for Open and Flexible Learning, 1-237. https://doi. org/10.4324/9780203966280

Koumi, J. (2014). Potent Pedagogic Roles for Video. Media and Learning Association, 1, 1-13. http://association.media-andlearning.eu/portal/resource/potent-pedagogic-roles-video

Lackmann, S., Léger, P. M., Charland, P., Aubé, C., \& Talbot, J. 
(2021). The Influence of Video Format on Engagement and Performance in Online Learning. Brain Sciences, 11(2), 1-21. https://doi.org/10.3390/brainsci11020128

Le Fevre, D. M. (2003). 9. Designing for Teacher Learning: VideoBased Curriculum Design. Advances in Research on Teaching, 10, 235-258. https://doi.org/10.1016/S1479-3687(03)10009-0

Linebarger, D. L. (2001). Learning to Read from Television: The Effects of Using Captions and Narration. Journal of Educational Psychology, 93(2), 288-298. https://doi.org/10.1037/00220663.93.2.288

Markham, P., \& Peter, L. (2003). The Influence of English Language and Spanish Language Captions on Foreign Language Listening/Reading Comprehension. Journal of Educational Technology Systems, 31(3), 331-341. https://doi.org/10.2190/ bhuh-420b-fe23-ala0

Moerdiyanto. (1989). Strategi Pelaksanaan "Pendekatan Keterampilan Proses" Dalam Kegiatan Belajar Mengajar. 1(1), 24-36. https://doi.org/10.21831/cp.v1i1.7731

Montero Perez, M., Peters, E., \& Desmet, P. (2014). Is less More? Effectiveness and Perceived Usefulness of Keyword and Full Captioned Video for L2 Listening Comprehension. ReCALL, 26(1), 21-43. https://doi.org/10.1017/S0958344013000256

Norland, E. V. T. (1990). Controlling Error in Evaluation Instruments. Journal of Extension, 28(2), 23-41.

Nurhidayat, E., \& Syarifah, E. F. (2019). TEDx TAlKS Program Sebagai Media Untuk Mempelajari Voice and Accent dalam Pembelajaran. Seminar Nasional Pendidikan, FKIP UNMA 2019 "Literasi Pendidikan Karakter Berwawasan Kearifan Lokal Pada Era Revolusi Industri 4.0," 1438-1445.

Pappas, I. O., Mikalef, P., \& Giannakos, M. N. (2016). Video-based Learning Adoption: A Typology of Learners. CEUR Workshop Proceedings, 1579(April), 34-41. https://doi.org/10.13140/ RG.2.1.1680.2163

Undang-Undang Republik Indonesia No. 20 Tahun 2003 tentang 
Sistem Pendidikan Nasional, 1 (2003).

Preradovic, N. M., Lauc, T., \& Panev, I. (2020). Investigating Interactivity in Instructional Video Tutorials for an Undergraduate Informatics Course. Issues in Educational Research, 30(1), 200-223.

Rahman, A., Masnayadi, M., Nerim, N., \& Muslim, M. (2019). Developing English Materials Based on Saintific Approach Through Islamic Content for Islamic Senior Hingh School Students. Journal of Languages and Language Teaching, 6(2), 86. https://doi.org/10.33394/jollt.v6i2.1259

Riana, E., \& Gafur, A. (2015). Pengembangan Multimedia Interaktif Pembelajaran Bahasa Inggrsi Materi Teks Deskriptif. Jurnal Inovasi Teknologi Pendidikan, 2(2), 212-224. https://doi. org/10.21831/tp.v2i2.7611

Rodgers, M. P. H., \& Webb, S. (2017). The Effects of Captions on EFL Learners' Comprehension of English-language Television Programs. CALICO Journal, 34(1), 20-38. https://doi. org/10.1558/cj.29522

Seckman, C. (2018). Impact of Interactive Video Communication Versus Text-Based Feedback on Teaching, Social, and Cognitive Presence in Online Learning Communities. Nurse Educator, 43(1), 18-22. https://doi.org/10.1097/NNE.0000000000000448

Siswanta, J. (2017). Pengembangan Karakter Kepribadian Anak Usia Dini (Studi Pada PAUD Islam Terpadu Di Kabupaten Magelang Tahun 2015). Inferensi, 11(1), 97. https://doi.org/10.18326/ infsl3.v11i1.97-118

Suradi, A. (2018). Penanaman Religiusitas Keislaman Berorientasi pada Pendidikan Multikultural di Sekolah. Jurnal Pendidikan Agama Islam (Journal of Islamic Education Studies), 6(1), 2543. https://doi.org/10.15642/jpai.2018.6.1.25-43

Suyadi, S. (2019). Integration of Anti-Corruption Education (PAK) In Islamic Religious Education (PAI) With Neuroscience Approach (Multi-Case Study in Brain Friendly PAUD: I Sleman Kindergarten Yogyakarta). INFERENSI: Jurnal Penelitian Sosial 
Keagamaan, 12(2), 307-330. https://doi.org/10.18326/infsl3. v12i2.307-330

Syaparuddin, S., \& Elihami, E. (2020). Peningkatan Motivasi Belajar Siswa Melalui Video pada Pembelajaran PKn di Sekolah Paket C. Jurnal Edukasi Nonformal, 1(1), 187-200. https:// ummaspul.e-journal.id/JENFOL/article/view/318

Tegeh, I. M., Simamora, A. H., \& Dwipayana, K. (2019). Pengembangan Media Video Pembelajaran Dengan Model Pengembangan 4D Pada Mata Pelajaran Agama Hindu. Mimbar Ilmu, 24(2), 158. https://doi.org/10.23887/mi.v24i2.21262

Wahyuni, S. (2015). Student Teams-Achievement Division To Improve Students' Writing Skill. Inferensi, 6(2), 1. https://doi. org/10.18326/infsl3.v8i1.1-22

Winarno, W. (2012). Hasil Pengujian Software Computerized Adaptive Testing (Cat) Mata Pelajaran Pendidikan Agama Islam (PAI) Dalam Membuat Rekam Medik Pembelajaran (Rmp) Untuk Mendiagnosis Kemampuan Siswa Di Sekolah. Inferensi, 6(2), 183. https://doi.org/10.18326/infs13.v6i2.183-204 